\title{
Control of fire blight (Erwinia amylovora) by a novel strain 49M of Pseudomonas graminis from the phyllosphere of apple (Malus spp.)
}

\author{
Artur Mikiciński • Piotr Sobiczewski • \\ Joanna Puławska $\cdot$ Robert Maciorowski
}

Accepted: 14 December 2015 / Published online: 28 December 2015

(C) The Author(s) 2015. This article is published with open access at Springerlink.com

\begin{abstract}
A bacterial isolate called 49M, showing protective activity against fire blight caused by the bacterium Erwinia amylovora, was selected from a large collection of isolates obtained from the apple phyllosphere and was identified as Pseudomonas graminis, based on its phenotype and sequence analysis of the $16 \mathrm{~S}$ rRNA and rpoD genes. The efficacy of strain 49M under laboratory and greenhouse conditions to protect apple blossoms and apple terminal shoots was equal or even higher than that of the reference strains A506 of Pseudomonas fluorescens and C9-1 of Pantoea vagans, as well as the bioproducts BlightBan A506, Blossom Protect and Hortocyna 18 SP (streptomycin), used for comparison. However, its activity on pear fruitlets was slightly less effective, but significantly better (over $10 \%$ ) than that of BlightBan A506. When strain 49M was introduced onto apple blossoms in orchards, it effectively colonised them during the entire bloom period, in different weather conditions, including rain. The strain showed no pathogenicity towards plant tissue (pear fruitlets, apple blossoms, tobacco leaves) and is therefore, a potential candidate for the development of a new biopesticide against fire blight.
\end{abstract}

Keywords Biocontrol - Antagonistic bacteria - Bacterial disease $\cdot$ Apple $\cdot$ Pear

A. Mikiciński • P. Sobiczewski $(\bowtie) \cdot J$. Puławska •

R. Maciorowski

Research Institute of Horticulture, 18 Pomologiczna Str.,

96-100 Skierniewice, Poland

e-mail: Piotr.Sobiczewski@inhort.pl

\section{Introduction}

Fire blight caused by Erwinia amylovora is a very severe bacterial disease of apple, pear and many other plant species, mainly of the Rosaceae family. It occurs in almost all pome fruit production regions of the world and causes damage of economic importance (Bonn and van der Zwet 2000). The disease affects all aboveground plant organs, causing their dieback. Flowers are the most important site of infection for epidemic fire blight occurrence, followed by the growing terminal shoots. The pathogen enters the host plants via natural openings such as the stigmas and nectaries of flowers, stomata, hydathodes or via wounds, and spreads systemically within plants. Common symptoms of fire blight are burn-like damage to flowers, leaves, fruits and terminal shoots and necrotic lesions and cankers develop on woody tissues (stem, branches) (Thomson 2000). The severity of disease is favoured by weather conditions such as high humidity and temperature, especially during vegetative growth. However, its occurrence is generally irregular and differs from season to season, even within the same orchard. Apart from the weather, the presence and amount of the infection source are also very important. In planning a disease control program, prediction systems such as Maryblyt or CougarBlight 2010 (van der Zwet et al. 2012) are very helpful. The control of fire blight is based on integrating various practices, including the application of protective treatments with copper-based preparations, phytosanitary pruning, the protection of wounds 
and the disinfection of pruning tools (Psallidas and Tsiantos 2000; van der Zwet et al. 2012). In some countries (e.g., the USA), treatments with antibiotics are also recommended, but their use in plant protection within the European Union, however, has only been permitted on an emergency basis, under tightly restricted conditions (Stockwell and Duffy 2012; Fried et al. 2013). Such legal requirements derive from the risk of positive selection of streptomycinresistant strains of E. amylovora and other bacteria that inhabit orchards and the possible negative impact on the environment. Furthermore, there is a fear that resistance might spread to human pathogens.

In recent years, the interest in finding new solutions for fire blight control has increased and has included the use of biocontrol agents, including antagonistic bacteria. This method represents an alternative to chemical applications and can also serve as a supplementary approach within an integrated strategy of disease control. Currently, to protect apple and pear trees during blooming, biopesticides based on the bacteria are registered and commercially available: Bloomtime (Pantoea agglomernas E325, USA), BlossomBless (P. agglomerans P10c, New Zeland), BlightBan C9-1 (P. vagans C9-1, USA), BlightBan A506 (Pseudomonas fluorescens A506, USA) and Serenade (Bacillus subtilis QST713, USA), as well as on yeast Aureobasidium pullulans (Blossom Protect, strain DSM 14940, Germany, and DSM 14941, Austria) - see Johnson and Stockwell 2000; Pusey and Wend 2012; Roselló et al. 2013. Research is also being carried out with the aim of improving the efficacy of these products as well as the selection of new effective strains with novel mechanisms of action and those that have a satisfactory effect on plant protection (Cabrefiga et al. 2011; Montesinos and Bonaterra 2009; Pusey and Wend 2012; Roselló et al. 2013).

We have shown in previous studies that bacterial isolates selected from populations of the apple phyllosphere are effective against fire blight (Sobiczewski et al. 2008; Mikiciński et al. 2008, 2011; Sobiczewski et al. unpublished data). Among those isolates, one called 49M formed yellow-pigmented colonies (Mikiciński et al. 2008). In this study, we identified 49M to be Pseudomonas graminis and we evaluated its ability to suppress fire blight in immature pear and apple flower assays, and its fitness on flowers in an orchard.

\section{Materials and methods}

Bacterial strains and commercial products

Strain 49M, which was isolated from the apple phyllosphere at the Pomological Orchard in Skierniewice, Poland, was selected from a group of 12 isolates that formed yellow-pigmented colonies and showed other similar morphological characters. The strain showed protective activity against fire blight in a screen of a large collection of isolates obtained from the apple phyllosphere, other plant species and soil (Mikiciński et al. 2008, 2011; Sobiczewski et al. unpublished data).

In our study on the identification and efficacy of 49M against fire blight, LMG 688 of Xanthomonas arboricola pv. corylina, EccUG (Pectobacterium carotovorum spp. carotovorum), A506 (Pseudomonas fluorescens) and C9-1 (Pantoea vagans) were used as a reference strains. The following commercial products registered for fire blight control were also included in the trials as standards: BlightBan A506 (strain A506 Pseudomonas fluorescens, Nufarm, USA) and Blossom Protect (Aureobasidium pullulans, Bio-ferm $\mathrm{GmbH}$, Austria), both prepared according to the manufacturer's instructions, and Hortocyna 18 SP (18\% streptomycin sulfate, Polfa, Poland).

A highly virulent wild strain of Erwinia amylovora, Ea659 was used for all efficacy trials. This strain was originally isolated from apple shoots in Poland in 1988. All strains were routinely stored in a mixture of PBS buffer with $20 \%$ glycerol at $-70{ }^{\circ} \mathrm{C}$.

Identification of isolate $49 \mathrm{M}$

\section{Phenotypic characterisation}

The following tests were performed, according to the keys of Bradbury (1988); Schaad et al. (2001); Holt et al. (1994), and Janse (2005): colony morphology, Gram reaction, spore formation, the presence of fluorescent pigment, the presence of oxidase and the oxidative/fermentative metabolism of glucose, nitrate reduction to nitrite, the presence of catalase, levan production from sucrose, indole production from tryptophan, the production of dihydrolase from arginine, the utilisation of glucose, lactose, raffinose, rhamnose, sucrose, mannitol, sorbitol, citric acid and the Voges-Proskauer test (Schaad et al. 2001). 
Additionally, due to the yellow colour of the bacterial colonies, the test for the presence of flexirubine, which is characteristic for some yellow-pigmented Flavobacterium strains, was performed (Christakis et al. 2005).

\section{DNA-based identification}

On the basis of the results of preliminary phenotypic characterisation, 49M DNA was first amplified with the primers X1 and X2, which are specific for bacteria of the genus Xanthomonas (Maes 1993). The type strain LMG 688 of Xanthomonas arboricola pv. corylina was included in the analysis as a reference. Because of a negative result of this test, isolate $49 \mathrm{M}$ was then identified by sequence analysis of the $800 \mathrm{bp}$-long fragment of the 5' end of $16 \mathrm{~S}$ rDNA. The DNA fragments amplified with $\mathrm{fD} 1$ and 800r primers (Weisburg et al. 1991; Drancourt et al. 1997) were directly sequenced and the obtained sequence was compared to those available in NCBI GeneBank (http://www.ncbi. nlm.nih.gov) using the BLASTn program to identify the closest relatives.

Based on BLASTn analysis of the 16S rRNA gene sequence and the classification of isolate $49 \mathrm{M}$ to the genus level, a fragment of the $r p o D$ gene was amplified with primers PsEG30F and PsEG790R, complementary to the $r p o \mathrm{D}$ gene of bacteria belonging to the genus Pseudomonas (Mulet et al. 2009). The obtained sequence was subjected to phylogenetic analysis together with rpoD sequences of type strains of other Pseudomonas species available in GenBank (as a reference). A maximum likelihood tree was generated by applying the Tamura-Nei evolutionary model with Gamma distribution (found as the best substitution model) and 1000 bootstrap replicates (MEGA 5 software package; Tamura et al. 2011).

\section{Growth on selective media}

To assess the growth ability of isolate $49 \mathrm{M}$, it was cultured on the following media, based on the results of phenotypic tests and DNA analysis: Cetrymide Agar (selective for Pseudomonas spp.) and MacConkey Agar (selective for Gram-negative bacteria) (Kado 1979). Growth and colony morphology were assessed $48 \mathrm{~h}$ after incubation of the bacteria at $25^{\circ} \mathrm{C}$.
Pathogenicity assays with the $49 \mathrm{M}$ isolate

The immature pear fruit assay of Sobiczewski and Millikan (1985) was modified to assess the pathogenicity of 49M. Immature pear fruit slices of cv. Conference were briefly dipped in a suspension of $49 \mathrm{M}$ $\left(1 \times 10^{7} \mathrm{CFU} \mathrm{mL} \mathrm{mL}^{-1}\right)$ or sterile water. Observations of any disease symptoms were performed within 7 days after inoculation.

The hypersensitive reaction (HR) on tobacco cv. Samsun was tested according to the method of Klement (1963) and the induction of HR was observed within $24 \mathrm{~h}$.

Pectolytic activity was tested on potato slices and crystal violet pectate (CVP) medium. Potato tubers, were washed in tap water, surface-sterilised by dipping for 5 min into $70 \%$ ethanol and were rinsed several times in sterile distilled water. The $10-\mathrm{mm}$ thick slices were placed on wet filter paper in Petri dishes and a loop of bacterial growth from NAS medium (Nutrient Agar $2.3 \%$, sucrose $5 \%$ ) was transferred and equally distributed onto their upper surface twice. After $2448 \mathrm{~h}$ incubation at $25{ }^{\circ} \mathrm{C}$, observations of rot development on potato slices were performed. The test on CVP medium was performed according to Cuppels and Kelman (1974). A bacterial suspension of $10^{8} \mathrm{CFU} \mathrm{mL}^{-1}$ in sterile water was spread with a glass rod onto the surface of the medium containing $0.2 \%$ crystal violet, $1.36 \% \mathrm{CaCl}_{2}$, $0.2 \% \mathrm{NaNO}_{3}, 0.5 \%$ sodium citrate, $0.1 \%$ Trypton, $1.8 \%$ polygalacturonic acid and $0.8 \%$ agar. The presence of characteristic pits around colonies after $48 \mathrm{~h}$ incubation at $27^{\circ} \mathrm{C}$ was considered to indicate pectolytic activity. As a positive control, strain EccUG of Pectobacterium carotovorum spp. carotovorum was used.

Efficacy of fire blight control by strain 49M

\section{Preparation of bacterial suspension}

Strain $49 \mathrm{M}$ and the reference strains were cultivated on NAS medium at $26{ }^{\circ} \mathrm{C}$ and were washed from the medium with sterile distilled water after $24 \mathrm{~h}$. The concentration of bacteria in the suspension was adjusted by measurement with a spectrophotometer (Semco S91E) at $630 \mathrm{~nm}$ and using serial dilutions and plating on NAS medium. The concentration of biological control strains was adjusted to $1 \times 10^{8} \mathrm{CFU} \mathrm{mL}^{-1}$. The concentration of Ea659 (E. amylovora) in all tests was $1 \times 10^{7} \mathrm{CFU} \mathrm{mL}^{-1}$. 


\section{Pear fruitlets assay}

This test was performed according to the method described by Sobiczewski and Millikan (1985) with slight modifications. The pear fruitlet slices of $\mathrm{cv}$. Conference were briefly dipped into a water suspension of the test strain or the commercial products prepared according to the manufacturer's instructions; sterile water was used as a negative control. The treated slices were immediately placed onto moist filter paper in $20 \mathrm{~cm}$-diameter Petri dishes. After $6 \mathrm{~h}$, the slices were inoculated by spraying the surface with Ea659. The evaluation of disease appearance on slices was performed after 3, 5 and 7 days of incubation at room temperature. The following scale was used: 0 - no symptoms, 1 - single drop/drops of bacterial ooze, 2 - several drops of ooze on about half the surface of the slice and small necrosis, 3 - ooze and necrosis on about half the surface of the slice, 4 - heavy ooze and necrosis on the entire slice. Each treatment was tested on at least 40 fruitlet slices (four replicates $\times 10$ slices).

\section{Test on apple blossoms}

The test was performed in a quarantine greenhouse on one-year-old apple trees cv. Idared growing in pots and on excised branches of apple cv. Jonagored, the basal ends of which were placed into beakers with water. Both cultivars showed different susceptibilities to fire blight. According to Le Lezec et al. (1997), 'Jonagold' ('Jonagored' is the mutant of 'Jonagold') has a low susceptibility, but 'Idared' is highly susceptible. Shoots or branches with blossoms in full bloom were sprayed with a suspension of the test strains and after spraying, they were covered with plastic bags. Commercial products were prepared according to the manufacturer's instructions. After $24 \mathrm{~h}$, blossoms were inoculated by spraying with a suspension of Ea659 and were again covered with plastic bags for a further $24 \mathrm{~h}$. The presence of fire blight symptoms on the flowers was recorded after 6 and 9 days on 'Idared' trees and after 5, 7 and 9 days on 'Jonagored' branches using the scale of Pusey (1999) with slight modifications: 0 - apparently healthy flower, 1 - necrosis visible on the flower nectary, 2 necrosis on the whole ovary, 3 - necrosis covering at least half the length of the peduncle, 4 - necrosis covering the flower, including whole peduncle. Each combination was applied on 'Idared' trees with five replicates with $30-40$ flowers in each replicate and on branches of 'Jonagored' with 60-70 flowers in each of five replicates.

\section{Test on apple shoots}

The tips of actively growing terminal shoots of oneyear-old apple M.26 rootstock in pots in the greenhouse were cut with sterile scissors under the first undeveloped leaf and were sprayed with a suspension of $49 \mathrm{M}$ strain or BlightBan A506 prepared according to manufacturer's instructions. Following the treatment, the shoots were covered with plastic bags. Inoculation was performed $6 \mathrm{~h}$ later by spraying with the suspension of Ea659 and immediately covering the shoots with plastic bags for $24 \mathrm{~h}$. The evaluation of the presence of fire blight was performed after 7, 10 and 17 days. The percentage of shoot necrosis was calculated at each time-point using the following formula: \% necrosis = necrosis length/shoot length $\times 100$. Each combination consisted of five replicates, each consisting of 15-16 shoots.

Survival on apple blossoms in orchard conditions

Apple blossoms in full bloom (5 May, 2009) on labelled branches (10 blossoms on five trees located in three rows) of trees cv. Jonagored growing at the Experimental Orchard in Dąbrowice/Skierniewice were sprayed with a suspension of 49M and C9-1 strains or with sterile water only (control). After 2, 6 and 10 days of the treatment, 10 blossoms were aseptically sampled and were transferred to individual sterile test tubes with $10 \mathrm{~mL}$ sterile water. After shaking for $15 \mathrm{~min}$, the number of bacteria in the rinsates was determined by serial dilutions and plating on NAS medium. The identity of representative colonies of 49M was confirmed by sequence analysis of the $16 \mathrm{~S}$ rDNA and rpoD genes. The weather parameters (daily maximum and minimum temperatures and precipitation) during the experimental period were recorded.

\section{Statistical analysis}

To test the effect of strains and commercial products on the biocontrol efficacy against Erwinia amylovora, oneway analysis of variance (ANOVA) was performed. Differences among means were compared by the Newman-Keuls test at $P=0.05$. Prior to analysis, data were transformed using the Box-Cox and Bliss (for 
percentage data) transformations to fulfil homoscedasticity and the normality assumption was checked using Levene's and Lillefors tests. All calculations were performed using STATISTICA software version 10.

\section{Results}

Identification of isolate $49 \mathrm{M}$

Isolate 49M formed small (about $1 \mathrm{~mm}$ in diameter), translucent and colourless colonies when incubated for $24 \mathrm{~h}$ on NAS medium. After 5 days, these colonies became yellow, circular, slightly convex with a regular smooth edge were up to $5 \mathrm{~mm}$ in diameter, without spilling onto the surface of medium. The cells were non-spore-forming Gram-negative rods. They showed oxidative metabolism of glucose, did not reduce nitrate to nitrite, produced catalase and oxidase, but were negative for the indol test and did not produce fluorescent pigment. Based on these characteristic, the isolate was initially classified to the genus Xanthomonas. However, no amplification product was observed after the reaction of 49M DNA with primers X1 and X2 specific for this genus, whereas a specific PCR product of $480 \mathrm{bp}$ was obtained with the type strain LMG 688 of Xanthomonas arboricola pv. corylina used as a reference. The BLASTn analysis of the $16 \mathrm{~S}$ rDNA sequence (LN901295) of isolate 49M showed over $99 \%$ similarity with the $16 \mathrm{~S}$ rDNA sequence of Pseudomonas graminis DSM $11363^{\mathrm{T}}$ (Y11150), Pseudomonas putida IAM $1236^{\mathrm{T}}$ (D84020) and Pseudomonas rhizosphaerae $\mathrm{IH}^{\mathrm{T}}$ (AY152673). However, the phylogenetic analysis based on the obtained rpoD gene sequence (LN901296) showed that it formed a single phylogenetic lineage with Pseudomonas graminis LMG $21611^{\mathrm{T}}$, with $95.7 \%$ sequence similarity (Fig. 1). Additional phenotypic tests confirmed the similarity of 49M to the type strain P294/ $08 \mathrm{~T}$ of P. graminis (Table 1). Based on these results, isolate $49 \mathrm{M}$ was identified as a strain of $P$. graminis. In additional assays, $P$. graminis $49 \mathrm{M}$ did not cause disease symptoms on pear fruitlets or induce HR on tobacco leaves, and showed no pectolytic activity on potato tuber tissue or CVP medium (Table 1). Also, no symptoms on apple blossoms treated with $49 \mathrm{M}$ only were observed (unpublished data). These test results confirmed that isolate $49 \mathrm{M}$ was $P$. graminis and can be considered as a strain.

\section{Efficacy of strain 49M in fire blight control}

Strain 49M was highly protective against fire blight on pear fruitlets, determined 3 and 5 days after inoculation with E. amylovora (Table 2). A subsequent evaluation (after 7 days) showed a slightly lower efficacy compared to that of strains A506 and C9-1 and Hortocyna 18 SP (streptomycin), but a significantly higher effect than bioproduct BlightBan A506. In the test on apple blossoms cv. Idared, strain $49 \mathrm{M}$ was as effective as other bacterial strains and BlightBan A506 during the first
Fig. 1 Maximum likelihood tree based on rpoD sequences of isolate $49 \mathrm{M}$ and type strains of all most closely related Pseudomonas species. Bootstrap values (expressed as percentages of 1000 replications) are given at the nodes. Bar - nucleotide substitutions per site

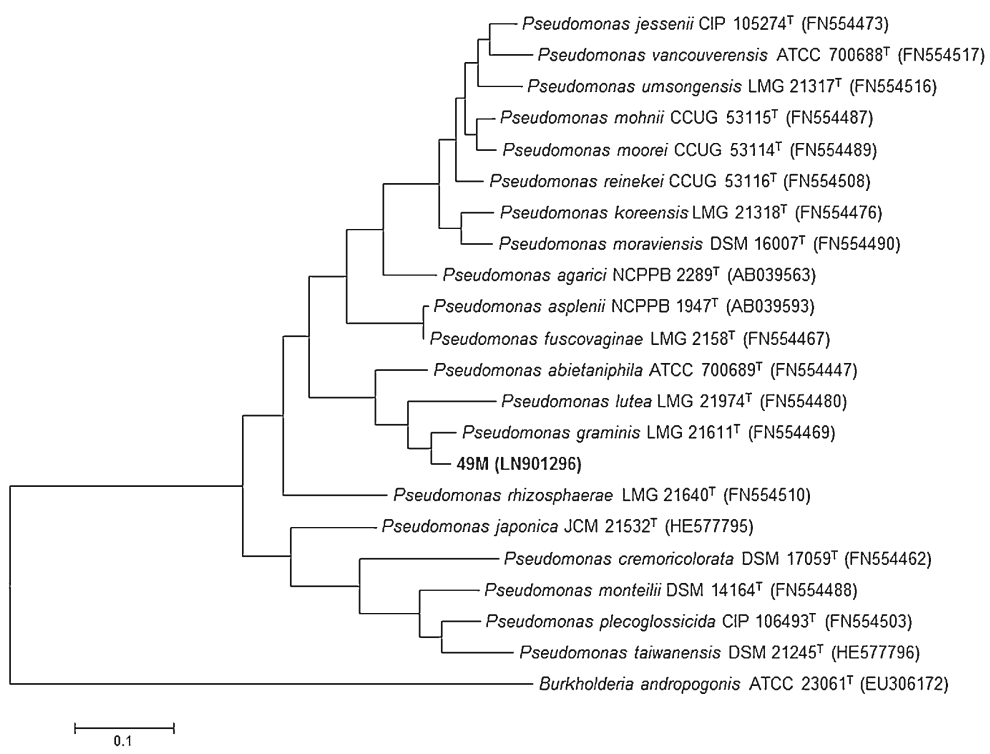


6 days after treatment (efficacy $80 \%$ ). The later assessment performed 9 days after the treatment, revealed a decrease in the efficacy of $49 \mathrm{M}$ to a level similar to that of the other two strains and BlightBan A506 used for comparison (Table 3 ).

In the experiment on apple blossoms cv. Jonagored, the protection by strain $49 \mathrm{M}$ was very high 5 days after inoculation with E. amylovora (efficacy $92.5 \%$ ) and

Table 1 Phenotypic characteristic of strain 49M in comparison with the type strain of Pseudomonas graminis

\begin{tabular}{|c|c|c|}
\hline Character & $49 \mathrm{M}$ & $\begin{array}{l}\text { Type strain } \\
\text { P } 294 / 08^{\mathrm{T}} *\end{array}$ \\
\hline Colony colour & Yellow & Yellow \\
\hline Gram reaction $(\mathrm{KOH})$ & - & - \\
\hline Spore formation & - & - \\
\hline Cell morphology & rod & rod \\
\hline Presence of oxidase & - & - \\
\hline Metabolism** & $\mathrm{O}$ & $\mathrm{O}$ \\
\hline Nitrate reduction to nitrite & - & - \\
\hline Fluorescent pigment & - & - \\
\hline Catalase & + & + \\
\hline Indol production & - & - \\
\hline Levan & - & - \\
\hline Arginine dihydrolase & - & - \\
\hline \multicolumn{3}{|l|}{ Utilization of: } \\
\hline Citric acid & + & + \\
\hline Glucose & + & + \\
\hline Lactose & - & - \\
\hline Mannitol & + & + \\
\hline Melibiose & - & - \\
\hline Raffinose & - & - \\
\hline Rhamnose & - & - \\
\hline Sorbitol & + & + \\
\hline Sucrose & - & - \\
\hline Xylitol & + & + \\
\hline Voges-Proskauer reaction & - & - \\
\hline Flexirubine presence & - & ND \\
\hline \multicolumn{3}{|l|}{ Growth on: } \\
\hline MacConkey agar & + & + \\
\hline Cetrymide agar & + & ND \\
\hline Tobacco HR & - & ND \\
\hline \multicolumn{3}{|l|}{ Pectolytic activity on: } \\
\hline potato slices & - & ND \\
\hline CVP medium & - & ND \\
\hline
\end{tabular}

*According to Behrendt et al. 1999

**O-oxidative; ND no data, + positive, - negative
Table 2 Severity of fire blight on immature pear fruit slices cv. Conference treated with bacterial suspensions of 49M, A506, or C9-1, a commercial formulation of A506, or Hortocyna (streptomycin) prior to inoculation with Erwinia amylovora Ea659

\begin{tabular}{llll}
\hline $\begin{array}{l}\text { Bacterial strain/ } \\
\text { preparation }\end{array}$ & \multicolumn{3}{l}{ Days after inoculation } \\
\cline { 2 - 4 } & 3 & 5 & 7 \\
\hline Control (water) & $1.0^{*} \pm 0.00 \mathrm{a}$ & $3.6 \pm 0.06 \mathrm{a}$ & $4.0 \pm 0.00 \mathrm{a}$ \\
$49 \mathrm{M}$ & $0.1 \pm 0.03 \mathrm{~b}$ & $0.4 \pm 0.16 \mathrm{c}$ & $0.9 \pm 0.28 \mathrm{c}$ \\
A506 & $0.0 \pm 0.00 \mathrm{~b}$ & $0.1 \pm 0.03 \mathrm{~d}$ & $0.1 \pm 0.05 \mathrm{~d}$ \\
C9-1 & $0.0 \pm 0.00 \mathrm{~b}$ & $0.1 \pm 0.00 \mathrm{~d}$ & $0.2 \pm 0.08 \mathrm{~d}$ \\
BlightBan A506 & $0.0 \pm 0.03 \mathrm{~b}$ & $0.8 \pm 0.18 \mathrm{~b}$ & $1.4 \pm 0.18 \mathrm{~b}$ \\
Hortocyna 0.06 \% & $0.0 \pm 0.00 \mathrm{~b}$ & $0.1 \pm 0.03 \mathrm{~d}$ & $0.3 \pm 0.05 \mathrm{~d}$
\end{tabular}

*Rating scale of severity: 0-4 (0-no necrosis, $4-$ total necrosis of slide); each treatment consisted of 40 slices $(10 \times 4$ replications); means within column followed by the same letter are not significantly different at $P<0.05$ according to Newman-Keuls test (means $\pm \mathrm{SE}$ )

was similar to that of other treatments (i.e., C9-1, Blossom Protect) (Table 4). During the experiment, the efficacy of all treatments decreased only slightly, but without significant differences among them. On the final (9th) day of the experiment, the greatest number of blossoms without fire blight symptoms were observed in the treatments with strain 49M (Fig. 2).

The protective treatment of injured apple terminal shoots of M.26 rootstock with 49M was effective during the whole period of the experiment (17 days) and ranged from $96.9 \%$, on the 7 th day after inoculation, to $86.2 \%$

Table 3 Severity of fire blight on apple blossoms cv. Idared treated with bacterial suspensions of 49M, C9-1, A506, or a commercial formulation of A506 prior to inoculation with Erwinia amylovora Ea659

\begin{tabular}{lll}
\hline $\begin{array}{l}\text { Bacterial strain/ } \\
\text { product }\end{array}$ & \multicolumn{2}{l}{ Days after inoculation: } \\
\cline { 2 - 3 } & 6 & 9 \\
\hline Control & $1.5^{*} \pm 0.12 \mathrm{a}(0.0)$ & $2.6 \pm 0.10 \mathrm{a}(0.0)$ \\
$49 \mathrm{M}$ & $0.3 \pm 0.03 \mathrm{bc}(80.0)$ & $1.0 \pm 0.06 \mathrm{~b}(61.5)$ \\
C9-1 & $0.2 \pm 0.03 \mathrm{c}(86.7)$ & $0.7 \pm 0.16 \mathrm{~b}(73.1)$ \\
A506 & $0.5 \pm 0.12 \mathrm{~b}(66.7)$ & $0.8 \pm 0.06 \mathrm{~b}(69.2)$ \\
BlightBan A506 & $0.3 \pm 0.07 \mathrm{bc}(80.0)$ & $1.0 \pm 0.07 \mathrm{~b}(61.5)$
\end{tabular}

*Rating scale of severity: $0=$ no necrosis; $4=$ total necrosis of ovary and peduncle; numbers in brackets show efficacy (\%); means within column followed by the same letter are not significantly different at $P<0.05$ according to Newman-Keuls test (means \pm SE) 
Table 4 Severity of fire blight on apple blossoms cv. Jonagored treated with bacterial suspensions of 49M, C9-1, or a Blossom Protect prior to inoculation with Erwinia amylovora Ea659

\begin{tabular}{llll}
\hline $\begin{array}{l}\text { Bacterial strain/ } \\
\text { product }\end{array}$ & \multicolumn{2}{l}{ Days after inoculation: } \\
\cline { 2 - 4 } & 5 & 7 & 9 \\
\hline Control & $0.4^{*} \pm 0.07 \mathrm{a}(0.0)$ & $1.3 \pm 0.09 \mathrm{a}(0.0)$ & $1.5 \pm 0.17 \mathrm{a}(0.0)$ \\
$49 \mathrm{M}$ & $0.03 \pm 0.01 \mathrm{~b}(92.5)$ & $0.2 \pm 0.07 \mathrm{~b}(84.6)$ & $0.4 \pm 0.09 \mathrm{~b}(73.3)$ \\
C9-1 & $0.01 \pm 0.0 \mathrm{~b}(97.5)$ & $0.1 \pm 0.06 \mathrm{~b}(92.3)$ & $0.5 \pm 0.12 \mathrm{~b}(66.7)$ \\
Blossom Protect & $0.03 \pm 0.02 \mathrm{~b}(92.5)$ & $0.2 \pm 0.03 \mathrm{~b}(84.6)$ & $0.5 \pm 0.03 \mathrm{~b}(66.7)$
\end{tabular}

*Rating scale of severity: $0=$ no necrosis; $4=$ total necrosis of ovary and peduncle; numbers in brackets show efficacy ( $\%)$; means within column followed by the same letter are not significantly different at $P<0.05$ according to Newman-Keuls test (means $\pm \mathrm{SE}$ )

on the 17th day. The application of BlightBan A506 was significantly less effective, at $30.8 \%$ (Table 5).

Colonisation of apple blossoms by strain 49M when applied in an orchard

Strain 49M established and maintained high populations on apple blossoms cv. Jonagored in an orchard up to 10 days after inoculation (Fig. 3). Two days after inoculation, the mean population of $49 \mathrm{M}$ was $4.5 \times 10^{6} \mathrm{CFU}$ flower $^{-1}$. Six and ten days after inoculation, the mean population ranged from $6.1 \times 10^{6}$ to $1.5 \times 10^{6} \mathrm{CFU}$ flower $^{-1}$, respectively. The populations of $49 \mathrm{M}$ did not differ significantly throughout the experiment. Similarly, the population of $P$. vagans C9-1 did not differ among the sampling times and showed a mean of $1.6 \times 10^{6}, 1.7 \times 10^{6}$ and $1.2 \times 10^{6} \mathrm{CFU}$ flower $^{-1}$ on 2 , 6 and 10 days after inoculation, respectively (Fig. 3). The sampling on sixth day was performed before rain.
The identity of the re-isolated bacteria was confirmed as 49M using molecular methods. On water-treated control blossoms, the population sizes of indigenous bacteria ranged from $2.0 \times 10^{2}$ to $4.0 \times 10^{5} \mathrm{CFU}$ flower $^{-1}$. The indigenous bacteria were phenotypically and genetically different to colonies of 49M. The colony morphology of the indigenous isolates also differed from that of C9-1. The weather during the orchard experiment varied, with high temperatures ranging from $12{ }^{\circ} \mathrm{C}$ to $25^{\circ} \mathrm{C}$, low temperatures from $7{ }^{\circ} \mathrm{C}$ to near freezing, and four days with measureable rain (Fig. 3).

\section{Discussion}

This study aimed to detect and select effective bacterial isolates against fire blight and showed that the apple phyllosphere and the environment of other plants are inhabited by bacteria that show potential activity for the
Fig. 2 Control of fire blight on blossoms (cv. Jonagored) treated with 49M, C9-1, or the commercial yeast formulation Blossom Protect and then inoculated with Erwinia amylovora Ea659. Notice: The number of diseased flowers was assessed 5 and 9 days after inoculation. Bars represent the mean percent blossoms without symptoms of fire blight and the vertical lines represent the standard error. For each time point, bars with the same letter are not significantly different at $P<0.05$ according to NewmanKeuls test

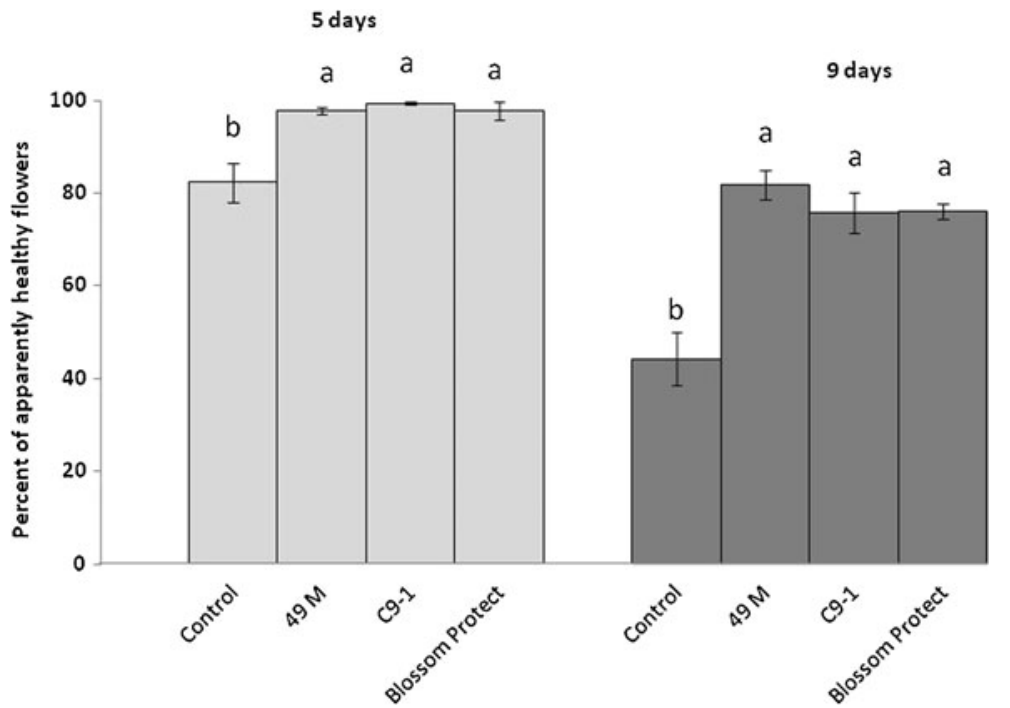


Table 5 Severity of fire blight on apple shoots M.26 treated with bacterial suspensions of 49M, or a commercial formulation of A506 prior to inoculation with Erwinia amylovora Ea659

\begin{tabular}{llll}
\hline Bacterial isolate/product & \multicolumn{2}{l}{ Days after inoculation } & \\
\cline { 2 - 4 } & 7 & 10 & 17 \\
\hline Control & $6.5^{*} \pm 0.65 \mathrm{a}(0.0)$ & $21.0 \pm 5.22 \mathrm{a}(0.0)$ & $37.7 \pm 3.26 \mathrm{a}(0.0)$ \\
$49 \mathrm{M}$ & $0.2 \pm 0.18 \mathrm{~b}(96.9)$ & $1.6 \pm 0.91 \mathrm{c}(92.4)$ & $5.2 \pm 1.41 \mathrm{c}(86.2)$ \\
BlightBan A506 & $6.0 \pm 0.66 \mathrm{a}(7.7)$ & $9.0 \pm 1.27 \mathrm{~b}(57.1)$ & $16.8 \pm 1.49 \mathrm{~b}(55.4)$ \\
\hline
\end{tabular}

*Length of shoot lesion/total length of shoot $\times 100$; numbers in brackets show efficacy (\%); means within column followed by the same letter are not significantly different at $P<0.05$ according to Newman-Keuls test (means $\pm \mathrm{SE}$ )

biocontrol of this disease (Sobiczewski et al. 2008; Mikiciński et al. 2008; Kabeil et al. 2010; Gerami et al. 2013; Roselló et al. 2013. One isolate (49M) was selected from a group of 24 bacterial isolates characterised by yellow-pigmented colonies, originating from symptomless apple leaves cv. Idared (Mikiciński et al. 2011). Preliminary identification of these isolates classified 12 as Pantoea agglomerans, whereas the others, including $49 \mathrm{M}$, possessed features similar to bacteria of the genus Xanthomonas (unpublished data). However, the identification based on sequence analysis of the 16S rRNA and rpoD genes, allowed the 49M isolate to be classified as Pseudomonas graminis. Yellow-pigmented pseudomonads that show efficacy against fire blight have been reported infrequently in the literature as showing potential to control fire blight. Manceau et al. (1990) found that such bacteria strongly colonised blossoms and leaves of pear trees and were more often detected than Pantoea agglomerans or Pseudomonas fluorescens. They also documented that epiphytic Pseudomonas syringae and yellow-pigmented pseudomonads formed $90 \%$ of the total bacterial population. Based on these findings, they suggested that effective isolates should be selected from among good leaf colonisers or be modified using genetic engineering (Manceau et al. 1990). However, from studies on these bacteria using only a few identification tests, they could only be classified to the genus level. Some studies dealing with bacteria suitable for biocontrol against fire blight have used the term "yellow colored bacteria", without a detailed identification/characterisation of the strains (McIntyre et al. 1973; Wrather et al. 1973; Isenbeck and Schulz 1986; Vanneste et al. 1992).

Pseudomonas graminis was isolated initially from the phyllosphere of grasses in Germany by Behrendt et al. (1999), who also characterised and named it. They found that a group of aerobic Gram-negative rod bacteria with polar flagella, formed yellow colonies that did not produce fluorescent pigment on King B medium, or reduced nitrate to nitrite, were also oxidase-negative and were unable to oxidise or ferment glucose to produce acid, but utilised a wide spectrum of carbon sources. Detailed identification studies including DNA-based analysis, revealed that all of these bacteria belonged to the genus Pseudomonas and showed low homology to other species of the genus. Based on this study, the new species P. graminis was identified (Behrendt et al. 1999). Bazzi et al. (2006) studied bacteria with protective activity against fire blight on apple blossoms and classified some as $P$. graminis, based on $16 \mathrm{~S}$ rDNA sequences. However, using fatty acid analysis, these strains showed intermediate characteristics between those of Pseudomonas cichorii and various pathovars of $P$. syringae. Recently, Alegre et al. (2013) reported that the strain CPA of $P$. graminis, originally isolated from apple, reduced the population of foodborne pathogens (Salmonella, Listeria monocytogenes) on minimally processed apple and peach fruits.

Strain 49M effectively protected pear fruitlets cv. Conference against fire blight, although to a slightly lower level than that of A506 and C9-1 strains and the streptomycin product Hortocyna 18 SP. On the other hand, the ability of $49 \mathrm{M}$ to protect 'Idared' apple blossoms was very high $(80.0 \%)$ during the initial days of the experiment, and similar to the reference treatments, subsequently slightly decreased. However, the efficacy of 'Jonagored' apple blossom protection remained at a high level (81.7-97.6\%) throughout the whole experiment (9 days). The susceptibility to fire blight in natural conditions differed between the cultivars, with 'Idared' being highly susceptible, and 'Jonagored' having a low suseptibility (Le Lezec et al. 1997). 

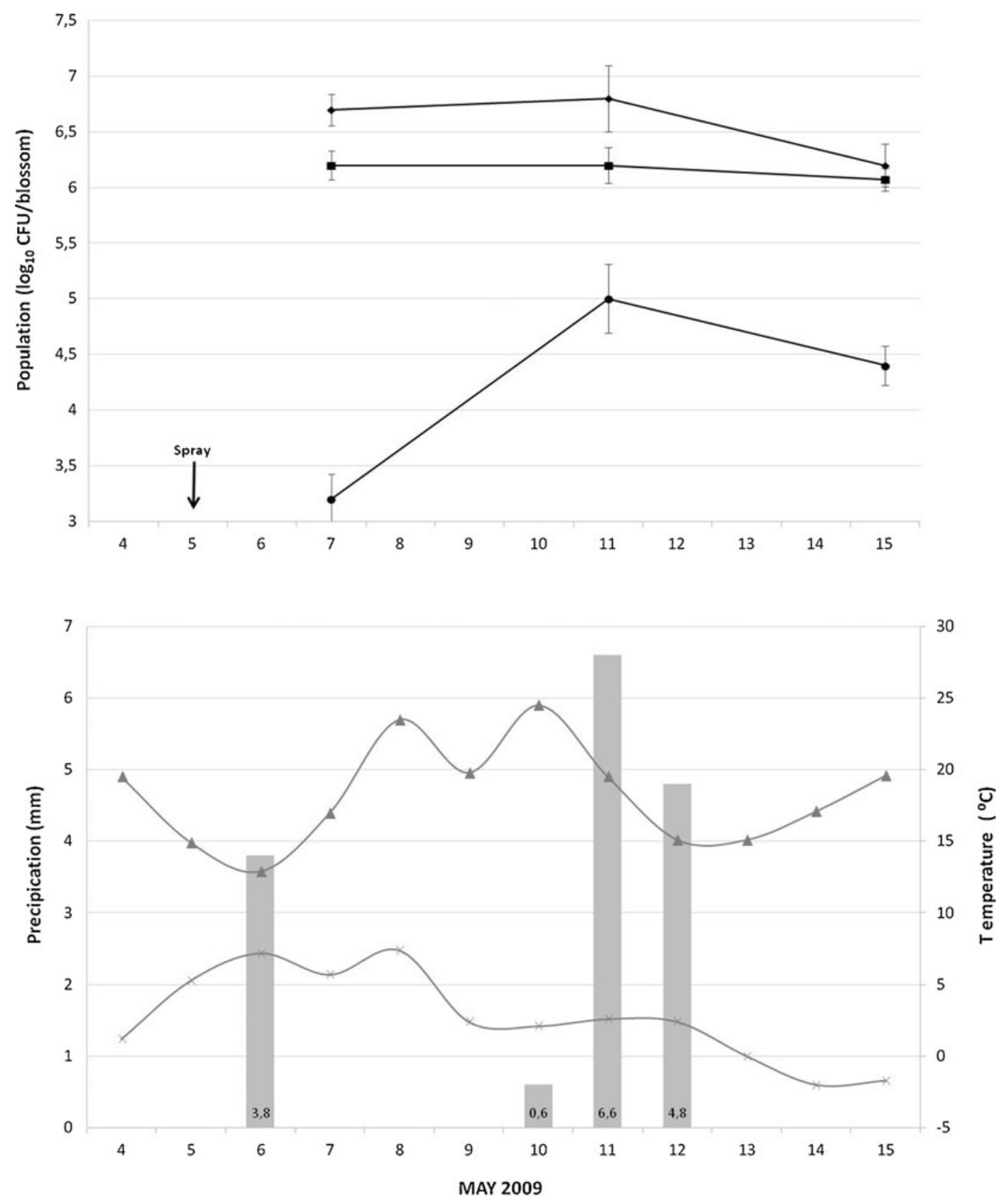

Fig 3 Population dynamics of 49M or C9-1 on blossoms on labelled branches of apple trees (cv. Jonagored) in an orchard. Notice: Strain $49 \mathrm{M}$ or C9-1 $\left(1 \times 10^{7} \mathrm{CFU} \cdot \mathrm{mL}^{-1}\right)$ or water were sprayed on labelled branches of apple trees in full bloom (May 5th, 2009). Upper panel: Mean population sizes and standard error of 49M (solid square), C9-1 (solid triangle) or indigenous bacteria (filled circle) on water-treated trees were estimated 2, 6, and

Strain 49M was very effective in protecting M.26 apple terminal shoots during a 17-day-long experiment, and was significantly more effective
10 days after inoculation (day marked with asterisk and 'Spray'). Population data was transformed to $\log 10$ prior to analysis (Newman-Keuls test at $P=0.05$ ). Lower panel: Environmental conditions. Bars represent precipitation in $\mathrm{mm}$ and lines present the daily maximum (triangle) and minimum (square) temperatures $\left({ }^{\circ} \mathrm{C}\right)$

than BlightBan A506 (Mikiciński et al. 2011). Nevertheless, this higher efficacy might be due to the high cell concentration of strain 49M used in our 
experiments $\left(1 \times 10^{8} \mathrm{CFU} \mathrm{mL}^{-1}\right)$ in comparison to that of the biopesticide $\left(1 \times 10^{7} \mathrm{CFU} \mathrm{mL} \mathrm{mL}^{-1}\right)$, which was prepared according to the manufacturer's instructions (Stockwell and Stack 2007). Another factor that might have affected this result is the length of the period between treatment and inoculation with E. amylovora. Strain A506 is very effective in disease control when applied to pear flowers $72 \mathrm{~h}$ before inoculation with E. amylovora (Wilson and Lindow 1993). Although no data are available regarding the efficacy of A506 on terminal shoots, Vanneste et al. (2006) pointed out that the number of CFU of A506 after application to apple leaf surfaces can drastically decrease even $7 \mathrm{~h}$ after application. In our experiment, strains 49M and A506 were applied to wounded shoots only $6 \mathrm{~h}$ prior to inoculation with the pathogen, in an attempt to avoid a bias in the results due to such an effect. Furthermore, we have found that an extension (up to $24 \mathrm{~h}$ ) of the period between antagonist application and inoculation with Ea659 caused a drastic decrease in the appearance of disease on treated shoots (data not shown). The experiments of Ülke and inar (1999) on shoots of pear cv. Deveci also demonstrated that six selected strains of Erwinia herbicola (syn. Pantoea spp.) showed a higher (up to $80 \%$ ) efficacy in controlling fire blight when a $24 \mathrm{~h}$ time interval between the application of antagonists and pathogen inoculation was used.

Biological preparations based on bacteria can vary in their effect under field conditions in comparison with chemical products based on copper, depending on adverse environmental conditions for the establishment of the biocontrol agent biological preparation, particularly dryness (Stockwell et al. 1998; Montesinos 2003; Bazzi et al. 2006). The strain 49M used here under partly controlled greenhouse conditions, showed a high protective activity on apple terminal shoots and blossoms. Moreover, this strain survived well on blossoms in orchards throughout the entire bloom period, despite changing weather conditions, including rainfall, which is considered very important for its practical application. The colonisation of plant organs that are infection sites for the pathogen is a key feature for biocontrol success. From an epidemiological perspective, the most important period for control is the first three days after a flower opens, when flowers are highly susceptible to infection (Gouk and Thomson 1999). Bazzi et al. (2006) demonstrated that pseudomonads that were artificially applied to apple blossoms survived effectively in the orchard for 15 days. The population dynamics of the 49M strain on apple blossom was very similar to those of A506 Pseudomonas fluorescens on pear pistils (Wilson and Lindow 1993) and C9-1 Pantoea vagans (formerly identified as Erwinia herbicola) on the stigmas and styles of apple (Stockwell et al. 1998). The results of other authors indicate that a mean temperature of about $4{ }^{\circ} \mathrm{C}$ can limit the number of surviving bacteria and affect their biocontrol activity (Nuclo et al. 1998).

In conclusion, strain $49 \mathrm{M}$ is highly protective against fire blight on different plant tissues (up to $73.3 \%$ on flowers and $86.2 \%$ on terminal shoots, respectively, compared to the controls) and survived well $\left(6.7 \times 10^{6} \mathrm{CFU}\right.$ flower $\left.{ }^{-1}\right)$ during the entire bloom period in an orchard. This is the first report showing that Pseudomonas graminis strain $49 \mathrm{M}$ is a prospective candidate for future development as a biopesticide against fire blight.

Acknowledgments The authors wish to express their thanks for kind providing the reference strains used in this study: to dr. Virginia O. Stockwell (Oregon State University, Corvallis, USA) - strains A506 and C9-1. We are also thankful to dr. Virginia O. Stockwell for biopreparation BlightBan A506. The useful comments of dr. Eligio Malusá during the manuscript preparation as well as technical help of Mrs. Danuta Rasz-Zając and Mrs. Dominika Niedzielska is greatly appreciated.

Open Access This article is distributed under the terms of the Creative Commons Attribution 4.0 International License (http:// creativecommons.org/licenses/by/4.0/), which permits unrestricted use, distribution, and reproduction in any medium, provided you give appropriate credit to the original author(s) and the source, provide a link to the Creative Commons license, and indicate if changes were made.

\section{References}

Alegre, I., Viñas, I., Ussal, J., Angeuer, M., Altisent, R., \& Abadias, M. (2013). Antagonistic effect of Pseudomonas graminis CPA-7 against foodborne pathogens in fresh-cut apples under simulated commercial conditions. Food Microbiology, 33, 139-148.

Bazzi, C., Biondi, E., \& Vanneste, J. L. (2006). Potential as biological control agents of some novel epiphytic bacterial strains isolated from Italy. Acta Horticulturae, 704, 329-336.

Behrendt, U., Ulrich, A., Schumann, P., Erler, W., Burghardt, J., \& Seyfarth, W. (1999). A taxonomic study of bacteria isolated from grasses: a proposed new species Pseudomonas graminis sp. nov. International Journal of Systematic Bacteriology, 49, 297-308.

Bonn, W. G., \& van der Zwet, T. (2000). Distribution and economic importance of fire blight. In J. L. Vanneste (Ed.), Fire blight - the disease and its causative agent, Erwinia amylovora (pp. 37-53). UK: CAB International, Wallingford. 
Bradbury, J. F. (1988). Identification of cultivable bacteria from plants and plant tissue cultures by use of simple classical methods. Acta Horticulturae, 225, 27-37.

Cabrefiga, J., Francés, J., Montesinos, E., \& Bonaterra, A. (2011). Improvement of fitness and efficacy of a fire blight biocontrol agent via nutritional enhancement combined with osmoadaptation. Applied and Environmental Microbiology, 77, 3174-3181.

Christakis, G. B., Perlorentzou, S. P., Chalikiopoulou, I., Athanasiou, A., \& Legakis, N. J. (2005). Chryseobacterium indologenes non-catheter-related bacteremia in a patient with a solid tumor. Journal of Clinical Microbiology, 43, 20212023.

Cuppels, D., \& Kelman, A. (1974). Evaluation of selective media for isolation of soft rot bacteria from soil and plant tissue. Phytopathology, 64, 468-475.

Drancourt, M., Bollet, C., \& Raoult, D. (1997). Stenotrophomonas africana sp. nov., an opportunistic human pathogen in Africa. International Journal of Systematic Bacteriology, 47, 160163.

Fried, A., Schell, E., Moltman, E., \& Wensing, A. (2013). Control of fire blight in Baden-Württenberg at the end of the streptomycin era. Acta Horticulturae, 1056, 5556.

Gerami, E., Hassanzadeh, N., Abdollahi, H., Ghasemi, A., \& Heydari, A. (2013). Evaluation of some bacterial antagonists for biological control of fire blight disease. Journal of Plant Pathology, 95, 127-134.

Gouk, S. C., \& Thomson, S. V. (1999). Influence of age apple flowers on growth of Erwinia amylovora. Acta Horticulturae, 489, 525-527.

Holt, J. G., Krieg, N. R., Sneath, P. H. A., Staley, J. T., \& Williams, S. T. (1994). Bergey's manual of systematic bacteriology. Willimas \& Wilkins, Baltimore: Ninth Edithion. USA.

Isenbeck, M., \& Schulz, F. A. (1986). Biological control of fire blight (Erwinia amylovora [Burr.] Winslow et al.) on ornamentals. II. Investigation about the mode of action of the antagonistic bacteria. Journal of Phytopathology, 116, 308314.

Janse, J. D. (2005). Phytobacteriology, principles and practice (p. 360). CABI Publishing.

Johnson, K. B., \& Stockwell, V. O. (2000). Biological control of fire blight. In J. L. Vanneste (Ed.), Fire blight - the disease and its causative agent, Erwinia amylovora (pp. 319-337). UK: CAB International, Wallingford.

Kabeil, S. S., Fayed, M. I., Amar, M. A., \& Al-Far, I. M. (2010). Antagonistic activity of some bacterial isolates against Erwinia amylovora. American-Eurasian Journal of Agricultural \& Environmental Sciences, 8, 588-596.

Kado, C. I. (1979). Methods in plant bacteriology (p, 80). Davis: University of California.

Klement, Z. (1963). Method for rapid detection of the pathogenicity of phytopathogenic Pseudomonas. Nature (London), 199, 299-300.

Le Lezec, M., Lecomte, P., Laurens, F., \& Michelesi, J. C. (1997). Sensibilité variétale au feu bactérien. L'Arboriculture Fruitiére, 503, 57-62.

Maes, M. (1993). Fast classification of plant-associated bacteria in the Xanthomonas genus. FEMS Microbiology Letters, 113, $161-166$
Manceau, C., Lalande, J. C., Lachaud, G., Chartier, R., \& Paulin, J. P. (1990). Bacterial colonization of flowers and leaf surface of pear trees. Acta Horticulturae, 273, 73-82.

McIntyre, J. L., Kuć, J., \& Williams, E. B. (1973). Protection of pear against fire blight by bacteria and bacterial sonicates. Phytopathology, 63, 872-877.

Mikiciński, A., Sobiczewski, P., \& Berczyński, S. (2008). Selection of bacteria from epiphytic populations on apple trees and soil environment for ability to control fire blight (Erwinia amylovora). Phytopathologia Polonica, 47, 43-55.

Mikiciński, A., Sobiczewski, P., Jakubowska, A., Puławska, J., \& Berczyński, S. (2011). Pseudomonas graminis as a biocontrol agent of fire blight. Acta Horticulturae, 896, 471-476.

Montesinos, E. (2003). Development, registration and commercialization of microbial pesticides for plant protection. International Microbiology, 6, 245-252.

Montesinos, E., \& Bonaterra, A. (2009). Microbial pesticides. In M. Schaechter (Ed.), Encyclopedia of microbiology (pp. 110 120). Third edition. Elsevier Inc.

Mulet, M., Bennasar, A., Lalucat, J., \& García-Valdés, E. (2009). An rpoD-based PCR procedure for the identification of Pseudomonas species and for their detection in environmental samples. Molecular and Cellular Probes, 23, 140-147.

Nuclo, R. L., Johnson, K. B., \& Stockwell, V. O. (1998). Secondary colonization of pear blossoms by two bacterial antagonists of the fire blight pathogen. Plant Disease, 82, 661-668.

Psallidas, P. G., \& Tsiantos, J. (2000). In J. L. Vanneste (Ed.), Fire blight: the disease and its causative agent, Erwinia amylovora (pp. 199-234). Wallingford: CAB International.

Pusey, P. L. (1999). Water relations and infection by Erwinia amylovora based on crab apple blossom model. Acta Horticulturae, 489, 521-524.

Pusey, P. L., \& Wend, C. (2012). Potential of osmoadaptation for improving Pantoea agglomerans E325 as biocontrol agent for fire blight of apple and pear. Biological Control, 62, 2937.

Roselló, G., Bonaterra, A., Francés, J., Montesinos, L., Badosa, E., \& Montesinos, E. (2013). Biological control of fire blight of apple and pear with antagonistic Lactobacillus plantarum. European Journal of Plant Pathology, 137, 621-633.

Schaad, N. W., Jones, J. B., \& Chun, W. (2001). Plant pathogenic bacteria (Third ed., ). USA: APS Press, St. Paul.

Sobiczewski, P., \& Millikan, D. F. (1985). Efficacy of chemicals for control of fire blight (Erwinia amylovora). Fruit Science Reports, 12, 27-34.

Sobiczewski, P., Mikiciński, A., Berczyński, S., \& Puławska, J. (2008). Biological control of fire blight on apple blossoms and shoots with epiphytic and soil bacteria. Acta Horticulturae, 793, 409-414.

Stockwell, V. O., \& Duffy, B. (2012). Use of antibiotics in plant agriculture. Scientific and Technical Review of the Office International des Epizooties, 31, 199-210.

Stockwell, V. O., \& Stack, J. P. (2007). Using Pseudomonas spp. for integrated biological control. Phytopathology, 97, 244 249.

Stockwell, V. O., Johnson, K. B., \& Loper, J. E. (1998). Establishment of bacterial antagonists of Erwinia amylovora on pear and apple blossoms as influence by inoculum preparation. Phytopathology, 88, 506-513. 
Tamura, K., Peterson, D., Peterson, N., Stecher, G., Nei, M., \& Kumar, S. (2011). MEGA5: molecular evolutionary genetics analysis using maximum likelihood, evolutionary distance, and maximum parsimony methods. Molecular Biology and Evolution, 28, 2731-2739.

Thomson, S. (2000). Epidemiology of fire blight. In J. L. Vanneste (Ed.), Fire blight: the disease and its causative agent, Erwinia amylovora (pp. 9-36). Wallingford: CAB International.

Ülke, G., \& inar, Ö. (1999). Biological control studies on fire blight caused by Erwinia amylovora (Burr.) Winslow et al. Acta Horticulturae, 489, 611-614.

van der Zwet, T., Orolaza-Halbrendt, N., \& Zeller, W. (2012). Fire blight, history, biology and management (421 pp). St. Paul, MN: APS Press.

Vanneste, J. L., Yu, J., \& Beer, S. V. (1992). Role of antibiotic production by Erwinia herbicola Eh252 in biological control of Erwinia amylovora. Journal of Bacteriology, 174, 27852796.

Vanneste, J. L., Cornish, D. A., Yu, J., \& Spinelli, F. (2006). Establishment and survival on apple and pear leaves of four biological control agents including Pantoea agglomerans P10c and Pseudomonas fluorescens A506. Acta Horticulturae, 704, 307-311.

Weisburg, W. G., Barns, S. M., Pelletier, D. A., \& Lane, D. J. (1991). 16S ribosomal DNA amplification for phylogenetic study. Journal of Bacteriology, 173, 697-703.

Wilson, M., \& Lindow, S. E. (1993). Interaction between the biological control agent Pseudomonas fluorescens A506 and Erwinia amylovora in pear blossoms. Phytopathology, 83, 117-123.

Wrather, J. A., Kuć, J., \& Williams, E. B. (1973). Protection of apple and pear fruit tissue against fire blight with nonpathogenic bacteria. Phytopathology, 63, 1075-1076. 